\title{
Peran Modal Intelektual Sumber Daya Manusia dalam Pengelolaan Festival yang Berkelanjutan (Studi Kasus Festival Ngayogjazz)
}

\author{
Yolanda Saftriliani Fadilah Arohmi \\ Universitas Pendidikan Indonesia Bandung \\ email: yolandasfaaa@gmail.com
}

\begin{abstract}
Abstrak
Penelitian ini dilatarbelakangi pengelolaan sebuah festival jazz yang dapat terselenggara di setiap tahunnya dengan konsep yang menarik yaitu diselenggarakan di desa-desa yang ada di Daerah Istimewa Yogyakarta. Penelitian mengenai Modal Sumber Daya Manusia Dalam Pengelolaan Festival yang Berkelanjutan. Studi Kasus Festival Ngayogjazz ini bertujuan untuk menjelaskan peran modal intelektual sumber daya manusia (mencakup pemimpin dan anggota organisasi) dalam pengelolaan Festival Ngayogjazz yang berkelanjutan. Adapun permasalahan dari penelitian ini adalah tentang proses membangun dan mengelola modal intelektual SDM yang merupakan aset tak berwujud yang dimiliki Organisasi Festival Ngayogjazz. Penelitian ini menggunakan metode kualitatif dengan pendekatan studi kasus. Adapun teknik yang digunakan adalah teknik wawancara semi terstruktur kepada direktur Festival Ngayogjazz. Hasil penelitian menjelaskan bahwa proses membangun dan mengelola modal intelektual SDM pada Organisasi Festival Ngayogjazz dilakukan dengan cara organik, dalam artian semua pengelolaannya berbasis pada asas kekeluargaan dan ciri khas Yogyakarta dalam hal bertukar pikiran sampai dengan mengambil keputusan.
\end{abstract}

Kata kunci: pengelolaan, modal intelektual, SDM, festival ngayogjazz.

\section{Abstract}

This research is based on the processing of a jazz festival that can be held annually with an interesting concept which is held in the villages in Yogyakarta. Research on human resources in sustainable festival management. This research of Ngayogjazz festival aims to explain the role of intellectual capital of human recourses (include leaders and members of the organization) in managing sustainable Ngayogjazz. festival. As the problems of this research are about the process of building and managing intellectual property of human resources which are intangible assets owned by Ngayogjazz festival. This research used qualitative with a study approach. The technique that used is the semi-structured interview to the director of Ngayogjazz. The result of the study explained that the process of building and managing intellectual property resources in the Ngayogjazz organization was done in an organic way. all the management is based on the principle of family and characteristic of Yogyakarta in terms of exchanging ideas to making decision.

Keywords: management, intellectual capital, human resources, ngayogjazz festival 


\section{PENDAHULUAN}

Berbicara mengenai festival tentunya bukan merupakan sesuatu yang asing lagi untuk diperbincangkan, khususnya festival seni pertunjukan. Kebutuhan masyarakat akan seni dan perayaan-perayaan menjadikan keberadaan festival seni pertunjukan menjadi semakin berkembang. Seperti di Indonesia hampir setiap daerah memiliki festival seni pertunjukan yang memiliki ciri khas masing-masing. Perhelatan atau pelaksanaan festivalfestival tersebut di setiap daerah diselenggarakan karena adanya kebutuhan masyarakat akan seni, baik untuk wadah berapresiasi maupun untuk memenuhi kebutuhan lainnya. Lebih lanjut menurut https://ilmuseni.com seni pertunjukan sebagai tontonan atau hiburan tidak banyak membutuhkan syarat, seni untuk kepentingan ini tidak terkait oleh misi tertentu. Cukup sebagai bentuk seni yang mampu memberikan kesenangan pada seorang atau sekelompok orang yang berada di di dalam lingkup sekitar pertunjukan.

Seni pertunjukan dapat berguna untuk sarana melepas kejenuhan dan menghilangkan penat bagi orang-orang yang sibuk dengan kegiatan keseharian. Sebagai contoh banyak festival-festival musik yang pada saat ini seakan menjadi kebutuhan masyarakat sebagai media untuk melepaskan diri dari rutinitas dan menjadikannya sebagai sebuah hiburan pelepas penat. Menurut https://ilmuseni.com juga bahkan hiburan yang menjadi salah satu kebutuhan wajib di tengah masyarakat urban saat ini justru menjelma sebagai gaya hidup. Orang akan terpenuhi kepuasannya ketika dapat menyaksikan hiburan dari pertunjukan seni yang mereka suka.

Seiring dengan banyaknya permintaan maupun kebutuhan masyarakat akan seni khususnya seni pertunjukan, mulai bermunculan organisasi-organisasi seni maupun nonseni yang mencoba memenuhi dan memfasilitasi kebutuhan masyarakat dengan membuat sebuah festival atau wadah pertunjukan seni lainnya. Seperti di Yogyakarta selain keberadaan Keraton Yogyakarta, identitas budaya Yogyakarta semakin diperlihatkan dengan banyaknya festival atau event bernuansa budaya yang dapat dinikmati. Ada banyak festival tahunan menurut http://www.klikhotel.com yang pelaksanaannya selalu semarak. Dari sekian banyak festival di Yogyakarta, berikut festival tahunan di Yogyakarta yang paling ditunggu di antaranya adalah Festival Grebeg Maulud (Sekaten), Festival Kesenian Yogyakarta, Ngayogjazz, Festival Gamelan Yogyakarta, Pasar Kangen, Pekan Budaya Tionghoa Yogyakarta, serta Festival Jajanan Kekoenoan dan Kekinian.

Namun keterlaksanaan festival-festival tersebut di setiap tahunnya bukan jadi satusatunya indikator yang dapat menyebutkan festival-festival tersebut sukses. Ada beberapa indikator kesuksesan sebuah pergelaran festival lainnya yang perlu dipertimbangkan. Menurut hasil catatan dari laman https://www.facebook.com/notes/universitas-gadjahmada indikator keberhasilan suatu event adalah kepuasan peserta/ undangan/ tamu. Ini berkaitan dengan kinerja panitia. Apakah ekspektasi peserta/undangan/tamu bisa terpenuhi, apakah pelayanan dan fasilitas yang diberikan panitia menunjang peserta/undangan/tamu dalam mengikuti event tersebut. Selain itu terdapat kesesuaian konsep acara, pelaksanaan acara, dan waktu. Persiapan sebelum event meliputi banyak hal. Menyusun konsep, menyusun kepanitiaan, menggalang dana, menarik peserta/undangan/dana, menyiapkan perlengkapan dan perlengkapan, membayar partisipan acara dan pekerja, sekaligus mengatur keberlangsungan acara dengan waktu yang tepat. Apabila acara berlangsung dengan lancar dan terkendali hampir dipastikan event tersebut telah sukses. Kemudian 
terdapat value added bagi Instansi. Bagaimana mengemas acara tersebut agar memiliki nilai tambah bagi instansi juga merupakan hal yang menarik. Tentu ini sejalan dengan visi misi instansi. Misal, instansi yang bergerak di bidang engineering tentu event yang diadakan berkisar tentang dunia engineering. Terakhir adalah profit. Tentu ada pula event yang di-setting nonprofit. Tak dipungkiri profit masih merupakan indikator yang cukup menonjol dari keberhasilan suatu event. Indikator keberhasilan sebuah event (dalam hal ini festival) tersebut juga merujuk pada tujuan apa yang hendak dicapai oleh festival tersebut.

Tujuan festival erat hubungannya dengan organisasi yang merencanakan dan mengelolanya. Sebuah organisasi menurut https://krjogja.com dapat mencapai tujuannya tergantung kepada pemimpin dan orang-orang yang ada di sekitarnya. Apabila suatu organisasi dipimpin orang baik, tanpa diberi aturan organisasi tersebut akan baik. Namun, jika dipimpin oleh orang yang tidak baik diberi berbagai aturanpun, maka hasilnya belum tentu baik.

Seorang pemimpin dalam organisasi keberadaannya memang penting. Namun, sumber daya manusia (dalam hal ini anggota) sebuah organisasi juga harus memiliki modal intelektual yang dapat menunjang tujuan yang hendak dicapai. Modal intelektual sendiri menurut https://kajianpustaka.com merupakan aset tidak berwujud berupa sumber daya informasi serta pengetahuan yang berfungsi untuk meningkatkan kemampuan bersaing serta dapat meningkatkan kinerja perusahaan/ organisasi. Adapun aspek-aspek yang terkandung dalam modal intelektual antara lain modal manusia, modal struktural, dan modal eksternal (mencakup konsumen dan relasi).

Seiring dengan pertumbuhan festival kesenian yang ada di Yogyakarta, banyak pula festival-festival yang mampu bertahan dari tahun ke tahun, namun ada pula yang tidak mampu menjaga eksistensinya menjadi wadah kesenian. Keterbatasan modal materi, kurangnya relasi, dan kurangnya kepercayaan dari masyarakat merupakan beberapa persoalan atau kendala yang sering dijumpai. Namun ada sebuah festival yang menurut https://www.guideku.com yaitu sebuah festival seni bernama Ngayogjazz yang diselenggarakan di kampung-kampung berbeda di setiap tahunnya. Ngayogjazz digagas dan didirikan oleh seorang seniman asal Yogyakarta bernama Gregorius Djaduk Ferianto, atau akrab disapa Djaduk. Adapun pertunjukan yang disuguhkan adalah pertunjukan musik jazz dan kolaborasi seni tradisi Indonesia dengan jazz sehingga memberikan suguhan musik baru yang berpotensi untuk mempromosikan produk seni lokal.

Kegiatan Ngayogjazz pertama kali diselenggarakan pada tahun 2007 hingga saat ini penyelenggaraan Ngayogjazz memasuki tahun ke-13. Adapun konsep atau gagasan besar dari penyelenggaraan Ngayogjazz adalah bagaimana menciptakan masyarakat pendukung produk seni. Jadi bukan hanya berbicara mengenai musisinya saja. Selain itu Ngayogjazz mencoba menghilangkan image mengenai musik jazz yang menurut http://jogjaeksis.blogspot.com mahal, eksklusif, elite, pertunjukan di gedung yang megah, penonton dengan pakaian rapi, lengkap dengan kemeja ataupun gaun. Di Ngayogjazz semua stereotipe itu hilang, yang ada adalah pertunjukan musik jazz gratis yang bisa dinikmati semua orang. Meskipun demikian, Ngayogjazz tetap menyajikan musik jazz yang berkualitas dan berkelas. Seperti pada perhelatannya pada tahun 2018 di Desa Gilangharjo, Pandak, Bantul ini Ngayogjazz mampu mendatangkan musisi nasional seperti Tompi, Idang Rasjidi, Margie Segers, Tohpati, dan banyak lagi. Tidak hanya musisi jazz 
nasional, adapula musisi mancanegara seperti Rodrigo Parejo Quartet (Spanyol), Nita Aartsen feat Jean-Sebastien Simonoviez (Perancis), Mikele Montolli (Italia), Kika Sprangers (Belanda), dan Ozma Quintet (Perancis). Tidak lupa Ngayogjazz pun mewadahi musisi-musisi jazz lokal yang berasal dari daerah-daerah di Indonesia yang membawa ciri khas daerahnya masing-masing seperti musisi jazz dari Surabaya, Samarinda, Pekanbaru, dan sebagainya.

Menurut http://koranbernas.id terdapat lebih dari 40 musisi yang tampil di Ngayogjazz 2018. Selain itu menurut http://repository.umy.ac.id Ngayogjazz dapat mendatangkan musisi lokal, nasional, hingga internasional tanpa dibayar. Kebutuhan musisi seperti penginapan, konsumsi, dan transportasi pun ditanggung oleh pihak sponsor yang tergabung di Ngayogjazz. Lebih lanjut ditambahkan oleh https://www.kompasiana.com, meskipun demikian tidak semua musisi yang mau tampil tanpa dibayar. Yang bersedia diajak adalah mereka yang benar-benar mau mendedikasikan talentanya tanpa memikirkan honor mereka. Jaringan dan kepercayaan juga merupakan aset yang harus dimiliki oleh para pengelola seni guna mempertahankan dan mengembangkan sesuatu yang sedang dijalani.

Menurut Djaduk pada wawancara dengan http://satuharapan.com gerakan ini bukan garapan yang bersifat money oriented, tapi inilah gerakan kebudayaan. Banyak orang mengatakan ini juga merupakan suatu investasi kultural. Maka proyek Ngayogjazz dikatakan proyek idealis atau proyek rugi. Namun seiring berjalannya waktu, Ngayogjazz akhirnya terbentuk dan dipercaya oleh pihak-pihak mitra seperti sponsor, vendor, pengisi acara, dan volunteer. Oleh sebab itu, dalam pengelolaannya masih jauh dari kata profesional (dalam hal bayaran) untuk panitia, volunteer, dan pengisi acara. Hanya saja kemitraan di Ngayogjazz berbasis pada pendekatan kekeluargaan.

Dari penjelasan mengenai Ngayogjazz sebelumnya, ada beberapa pernyataan yang muncul saat beberapa kali menghadiri kegiatan tersebut. Ngayogjazz dapat mendatangkan musisi-musisi mulai dari lokal, nasional, hingga internasional tanpa bayaran, sedangkan banyak penyelenggara sebuah festival atau pertunjukan seni harus membayar musisimusisi tersebut dengan harga yang ditawarkan musisi atau manajemennya. Selain itu, Ngayogjazz dapat dipercaya oleh pihak sponsor maupun penonton untuk dapat terlaksana di tahun-tahun berikutnya. Padahal jika dilihat dari kegiatannya, festival musik sudah banyak terselenggara di mana saja, khususnya di Yogyakarta. Dari pernyataan-pernyataan tersebut diasumsikan bahwa semua itu terjadi karena adanya peran modal intelektual yang meliputi modal manusia (sumber daya manusia) dan modal struktural organisasi Ngayogjazz, di mana kemampuan dan pengetahuan yang dimiliki pemimpin dan anggota organisasi Ngayogjazz menjadikan aset berharga untuk keberlanjutan organisasi. Modal struktural juga sama-sama memiliki peran yang penting juga karena tanpa adanya modal struktural, modal manusia hanyalah sejumlah sumber daya manusia dengan kemampuan dan pengetahuan yang tidak teroganisir. Selain itu modal sosial juga menjadi bagian yang penting, di mana organisasi Ngayogjazz telah mendapatkan kepercayaan baik dari masyarakat desa, penonton, musisi, sponsor, dan pihak-pihak lainnya.

Berdasarkan hal tersebut diasumsikan bahwa peran modal intelektual yang dimiliki SDM Organisasi Ngayogjazz menjadi penting dimiliki dan dikelola dengan baik, guna menciptakan festival seni pertunjukan yang berkelanjutan. Dengan demikian penelitian ini 
akan mengkaji mengenai permasalahan penelitian dengan pendekatan studi kasus, yaitu mencari peran modal intelektual dan modal sosial dalam menciptakan Festival Ngayogjazz yang berkelanjutan, sehingga memperoleh pengetahuan, strategi organisasi, dan membangun relasi untuk dapat terus menciptakan sebuah wadah seni yang bernilai dan bekelanjutan.

\section{Teori}

Teori Stakeholder atau pemangku kepentingan telah dikembangkan selama tiga puluh tahun terakhir. Selanjutnya teori ini dikembangkan oleh Freeman dalam bukunya yang berjudul Strategic Management: A Stakeholder Approach. Pada tahun-tahun berikutnya, literatur tentang teori pemangku kepentingan telah menjadi luas dan beragam. Teori ini telah memengaruhi berbagai bidang yang berbeda, termasuk manajemen strategis, keuangan, akuntansi, manajemen, pemasaran, hukum, perawatan kesehatan, kebijakan publik, dan lingkungan.

Kemuculan teori ini merupakan bentuk respon dari permasalahan yang muncul di bidang bisnis. Adapun masalah-masalah yang muncul antara lain masalah penciptaan nilai dan perdagangan. Untuk menjelaskan bagaimana dapat memahami dunia bisnis yang terdapat banyak perubahan dalam hubungannya dan di mana hubungan ini berubah tergantung pada konteks nasional, industri, dan masyarakat. Selanjutnya adalah masalah etika kapitalisme yang menjadi sarana dominan untuk mengatur penciptaan nilai dan perdagangan, menjadi jelas bahwa membatasi perhatian pada efek ekonomi menghasilkan pandangan parsial yang merusak. Terakhir adalah masalah pola pikir manajerial di mana manajer tidak dapat mengadopsi pola pikir yang menyatukan bisnis dan etika untuk membuat keputusan secara rutin. Selain itu bagaimana menangani turbulensi, globalisasi, dan etika menjadi bagian rutin dari pekerjaan manajer (Freeman, Harrison,Wicks, dkk, 2010:6-9).

\section{METODE}

\section{Pendekatan Penelitian}

Pada penelitian ini peneliti menggunakan metode kualitatif dengan pendekatan studi kasus.

\section{Lingkup Penelitian}

Penelitian ini dilakukan di Kantor Wartajazz (Jalan Munggur No. 20, Demangan, Gondokusuman, Kota Yogyakarta-55222). Di mana tempat ini menjadi ruang kumpul Organisasi Festival Ngayogjazz. Adapun yang menjadi objek formalnya adalah modal intelektual (yang meliputi modal manusia dan modal struktural), sedangkan yang menjadi objek materialnya adalah Organisasi Festival Ngayogjazz. Subjek pada penelitian ini adalah 10 narasumber yang terdiri dari direktur, manajer, panitia, volunteer, musisi, $M C$, dan penonton.

\section{Teknik Pengumpulan Data}

Teknik pengumpulan data pada penelitian ini adalah observasi dan wawancara semi terstruktur sebagai data primer, sedangkan yang menjadi data sekundernya adalah mencari dokumentasi berupa data catatan, artikel online, buku, surat kabar, majalah, 
notulensi rapat, dan sebagainya. Selain itu, penulis menggunakan dokumentasi pribadi berupa arsip pedoman wawancara, rekaman audio, dan hasil pengambilan gambar kegiatan penelitian.

\section{HASIL DAN PEMBAHASAN}

Ngayogjazz merupakan sebuah festival musik jaz yang diselenggarakan rutin di setiap tahunnya. Adapun terbentuknya kegiatan ini tidak lain dari kreativitas dan kepekaan seni yang dimiliki para seniman yang ada di Yogyakarta. Penggagas Nyayogjazz sendiri adalah Djaduk Ferianto yang merupakan seorang aktor dan juga musisi Indonesia. Peran Djaduk dalam membentuk kegiatan ini sangat besar. Dimulai dari kontribusi ide, konsep, tenaga, dan bahkan dengan sukarela memberikan dana pribadi guna terlaksananya kegiatan ini. Pada awal pembentukannya, Djaduk dibantu oleh dua orang rekannya yaitu Vindra dan Hattakawa. Mereka bertiga merupakan key person dari lahirnya Festival Ngayogjazz.

Ngayogjazz pertama kali diselenggarakan pada tahun 2007 di Padepokan Seni Bagong Kusudiardja, Kasihan, Bantul yang kebetulan milik keluarga Djaduk Ferianto. Adapun gagasan besar dari Ngayogjazz itu sendiri adalah,

... Bagaimana membangun pendukung produk seni? Kalo senimannya bikin karya 'kan sudah sering, tapi bagaimana, siapa sih pendukung produknya? Orang penyelenggara event 'kan orientasinya profit, senimannya juga berkarya juga menunggu job/orderan. Ada yang juga punya manajemen, ada juga yang punya album kemudian 'kan ujung-ujungnya mendapat nilai ekonomi, baik itu diundang pementasan atau itu jualan albumnya. Tetapi, karena mereka orientasinya pada aspek ekonomi, mereka lupa akan membangun. Siapa sih pendukung produknya? (Wawancara Ferianto, 12 Mei 2018)

Menyikapi pernyataan Ferianto di atas, bahwasanya penyelengaraan kegiatan ini berdasarkan kepada proses membangun masyarakat pendukung produk seni. Maka gerakan ini bukan gerakan yang bersifat business oriented, tetapi inilah gerakan kebudayaan. Banyak orang mengatakan juga, ini merupakan suatu investasi kultural. Maka, proyek Ngayogjazz ini dikatakan proyek idealis dan proyek rugi.

Selain itu Ngayogjazz juga berupaya untuk menyatukan seluruh elemen yang ada di masyarakat melalui sebuah festival musik jaz. Meskipun jaz diangkat sebagai judul besar festival ini, tetapi pada pelaksanaannya tidak hanya jaz saja. Terdapat pula unsur kearifan lokal yang terkandung di dalamnya.

Konsep lain dari Ngayogjazz adalah diselenggarakan di desa-desa. Tapi banyak yang terjebak hanya pada aspek eksotisme. Esensi sebenarnya adalah bagaimana kita belajar pada kearifan lokal. Setiap tahun Ngayogjazz berpindah tempat dari desa ke desa yang ada di Daerah Istimewa Yogyakarta, dengan beberapa macam desa yang setiap desa memiliki karakter tersendiri. Dari situlah terdapat pembelajaran dari mulai lingkungan, musisi, panitia, dan masyarakat desanya yang sama-sama belajar bagaimana pengelolaan kegiatan seni yang erat dengan masyarakat. Pendekatan di Ngayogjazz sendiri adalah melibatkan masyarakat yang tidak tahu pengelolaan seni.

Selain konsep, ada alasan kuat mengenai pemilihan genre jazz pada Festival Ngayogjazz. Secara image yang terbentuk di Indonesia jaz ini seakan-akan elite. Seperti yang dikemukakan Ferianto, 
...Itu juga dapat dikatakan anggapan yang salah kaprah. 'jazz sulit, jazz elit' dan bahkan itu juga dapat membangun lifestyle pemain-pemain jazz yang konon banyak lahir juga di ibu kota, terutama kota metropolis yang akhirnya terpengaruh dari kultur musik pop yang tujuan utamanya menjadi bintang. Sementara kita memahami jazz sendiri merupakan satu genre musik yang lahir dari suatu pergerakan dan sangat berbeda antara tempat lahirnya jazz dengan asumsi masyarakat Indonesia. (Wawancara Ferianto, 12 Mei 2018)

Ngayogjazz berupaya ingin mengembalikan lagi pada tingkat esensi dan semangat jazz. Ditambahkan Ferianto lagi,

...Nah kebetulan jazz yang kita pinjam sebagai satu medium kita untuk berbicara. Berbicara dari akhir kebudayaannya. Tapi ketika awal kita akhirnya memilih jazz itu adalah bagaimana kita ingin mencoba mendekonstruksi image jaz yang elit, kalo manggung harganya mahal, sulit dipahami oleh masyarakat yang didominasi oleh kultur pop tadi. Akhirnya kami mengemas jazz menjadi bentuk lain dan di situ saya sebut main di Ngayogjazz tentunya akan menemukan sesuatu yang berbeda. (Wawancara Ferianto, 12 Mei 2018)

Modal manusia pada konteks penelitian ini adalah salah satu aset yang dimiliki Organisasi Festival Ngayogjazz berupa pengetahuan, keterampilan, dan pengalaman yang dimiliki masing-masing pengelola mulai dari direktur, manajer, hingga anggota yang terlibat di pengelolaan Festival Ngayogjazz. Pengetahuan mengenai pengelolaan sebuah festival seni berkontribusi terhadap pembuatan gagasan, bertukar pikiran, hingga menelaah fenomena yang terjadi di masyarakat mengenai kebutuhan akan seni. Sebenarnya tidak hanya pengetahuan dengan cakupan yang sempit mengenai pengelolaan sebuah festival seni, tetapi pengetahuan mengenai aspek-aspek sosial dan kemanusiaan juga menjadi penting untuk dapat lebih rinci melihat fenomena yang ada saat ini. Pernyataan tersebut didukung oleh ungkapan narasumber, yaitu sebagai berikut,

... Wah kalo pengetahuannya pasti banyak kelengkapan-kelengkapannya. Umpamanya jelas pengetahuan dalam konteks ilmunya ada aspek antropologis, sosiologis, kemudian komunikasi, itu menjadi mutlak. Ketika saya bicara tentang komunikasi, bagaimana event ini harus menciptakan issue. Kemudian bagaimana meng-guide opini atau membangun opini kepada publik supaya mereka bisa hadir di dalam peristiwa itu. Issue itu menjadi sangat penting. (Wawancara Ferianto, 14 Mei 2019)

Dari ungkapan Ferianto tersebut, ternyata pengetahuan yang harus dimiliki pengelola festival menjadi cukup kompleks karena berhubungan juga dengan ide atau gagasan apa yang akan ditawarkan kepada masyarakat yang kemudian dapat diterima sebagai bentuk kontribusi pengelola untuk dapat mewadahi kebutuhan dan keinginan dari masyarakat.

Selain pengetahuan, selanjutnya keterampilan juga merupakan salah satu komponen penting yang mendukung pengelolaan Festival Ngayogjazz. Peran keterampilan yang dimiliki masing-masing stakeholder yang kemudian dituangkan dalam bentuk kreativitas-kreativitas ini yang kemudian menjadi pendukung dari pengetahuanpengetahuan yang sifatnya sebatas teori. Tentu saja keterampilan yang dimiliki para pengelola Festival Ngayogjazz tidak dapat disamaratakan satu sama lain, mengingat kebutuhan dan kapasitas kerja yang berbeda-beda. 
Pada dasarnya pengelolaan Festival Ngayogjazz tidak seperti sebuah manajemen pada umumnya. Namun di sini pengelolaannya lebih organik mengingat para stakeholder di Festival Ngayogjazz bukan berangkat dari orang-orang yang memiliki pengetahuan dan kemampuan manajemen secara akademisi, melainkan hasil dari pengalaman yang telah dimiliki masing-masing stakeholder-nya.

Modal manusia yang dimiliki Organisasi Festival Ngayogjazz tidak akan terarah jika tidak ada struktur yang menjadi pedoman jalannya sebuah pengelolaan. Untuk dapat mengelola sebuah festival yang optimal, diperlukan juga modal struktural yang menjadi pelengkap modal manusia yang dimiliki oleh Organisasi Festival Ngayogjazz. Dua modal ini merupakan sesuatu yang saling melengkapi dalam sebuah organisasi. Modal struktural yang pada konteks penelitian ini adalah sebuah tatanan berupa struktur, budaya organisasi, dan strategi Organisasi Festival Ngayogjazz.

Tujuh orang yang menjadi direktur dan manajer juga mengonsep semuanya. Tidak ada batasan atas ide maupun konsep, ketujuh orang ini memiliki hak yang sama dalam pelaksanaannya. Selain dapat saling melempar gagasan, tim Ngayogjazz ini juga menarik karena pola kerja komunal yang mengedepankan semangat komunitas. Dari ketujuh orang tersebut akhirnya dibagi-bagi wilayah kerjanya yang meliputi kesektretaiatan, markom, artistik (dalam artian membangun venue), pengurus musisi, sponsor, dan pengurus para volunteer.

Pada dasarnya pengelolaan Festival Ngayogjazz tidak seperti sebuah manajemen pada umumnya. Namun di sini pengelolaannya lebih organik mengingat para stakeholder di Festival Ngayogjazz bukan berangkat dari orang-orang yang memiliki pengetahuan dan kemampuan manajemen secara akademis, melainkan hasil dari pengalaman yang telah dimiliki masing-masing stakeholder dan anggotanya.

Dalam sebuah organisasi tentunya mengalami proses bertukar pikiran yang memiliki ciri khasnya masing-masing, tak terkecuali dengan Organisasi Festival Ngayogjazz. Ada hal menarik dalam proses bertukar pikiran organisasi ini yang dalam pembahasannya selalu random, dalam arti tidak sistematis.

...keputusan mengelola ide-ide segala macem dan itu dengan khas Ngayogjazz yang penuh guyonan, ya itulah khas kami khas Jogja dan yang tadi saya katakan, tidak sistematik. Tidak seperti organisasi yang mainstream, betul-betul step by step. Kita juga sebenarnya bikin blueprint nya, rekam schedule umpamanya. Tapi bisa kita dekonstruksi. Udah dibikin, rubaaah. Bisa kita main-mainkan. Kalo dibahasakan kreativitas itu tidak ada yang menghalangi. Muncul dengan spontan karena banyak hal yang setiap tahun berbeda-beda kasusnya. (Wawancara Ferianto, 14 Mei 2019)

Namun dalam hal mengambil keputusan, sama seperti manajemen pada umumnya, bahwa pengambil keputusan tertinggi itu adalah direkturnya. Meskipun demikian di Organisasi Festival Ngayogjazz semuanya masih bisa berubah sesuai dengan kebutuhan dan kondisi di lapangan. Mengingat ketetapan-ketetapan yang dibuat berdasarkan pengalaman pengelolaan sebelumnya yang belum tentu sama jika diterapkan pada tahun berikutnya.

Dalam sebuah organisasi seringkali terjadi perbedaan dalam hal apapun, baik itu yang sifatnya teknis maupun non teknis. Tidak jarang juga para stakeholder di Organisasi Festival Ngayogjazz mengalami perdebatan. Lagi-lagi ada acara khas yang dilakukan oleh 
para stakeholder ini. Faktor Yogyakarta juga menjadi salah satu ciri khas itu muncul, seperti yang dikatakan narasumber,

Perdebatan di dalam mengonsep Ngayogjazz dari tahun ke tahun itu penuh dengan perdebatan yang luar biasa. Tetapi karena kami tinggal di Jogja dan rata-rata juga temen-temen yang di board artistic itu orang Jogja, orang-orang pelaku kreatif di Jogja, dengan cara Jogja banget itu menjadi menarik karena saling mementahkan, tetapi menjadi bermusuhan. Dengan gaya guyonan khas Jogja, kadang-kadang bisa mentertawakan idenya sendiri. Tetapi kami meyakini perdebatan itu sebetulnya atau perbedaan pendapat itu bukan suatu permusuhan tetapi itu untuk menuju yang terbaik. Ya itu unik. Kalo orang tahu proses di kami, pasti orang kekaget-kaget itu. Terus kadang misalnya malam itu sudah diputuskan, kemudian bisa dirubah lagi karena ide muncul lagi, ngulang lagi. (Wawancara Ferianto, 14 Mei 2019)

\section{KESIMPULAN}

Modal intelektual yang meliputi modal manusia dan modal struktural memiliki peran penting untuk menciptakan festival yang berkelanjutan. Modal manusia di dalamnya terdapat pengetahuan, keterampilan, dan pengalaman yang dimiliki stakeholder dan anggota Organisasi Festival Ngayogjazz menjadikan aset tak berwujud ini menjadi salah satu faktor terciptanya pengelolaan yang optimal. Namun demikian hal itu dirasa kurang optimal jika tidak imbangi dengan pengelolaan modal struktural yang nantinya menjadi panduan. Adapun aspek modal struktural sendiri meliputi budaya organisasi, efektivitas struktural, dan strategi organisasi untuk bersamaan dengan modal manusia menciptakan festival yang berkelanjutan.

\section{KEPUSTAKAAN}

\section{Artikel Jurnal}

Haribawa, P. A., Avenzora, R., \& Arief, D. A. 2017. Analisis Orientasi Stakeholder Untuk Pembangunan Ekowisata di Wilayah Bali Aga, Buleleng-Bali. Jurnal Pariwisata. 22 (3), 269-276.

Junior, Duarte, Souza, dkk. 2014. The Influence of Intellectual Capital on Organizational Productivity: Literature Review. Journal of Economics. 97 (2), 106-120.

Linda, P. D \& Welty, P. J. 2012. Building a Legacy of Volunteers through Servant Leadership: A Cause-Related Sporting Event. Journal of Management and Leadership. 23 (2), 259-276.

Ricardson, J., Jogulu, U., \& Rentschler, R. 2017. Passion or people? Social Capital and Career Sustainability in Arts Management. Journal of Arts Management. 46 (8), $1835-1851$.

Simon, A, dkk. 2018. The Relationship of Hygiene, Motivator, and Professional Strategic Capabilities to the Performance of Australian Music Festival Event Management Organizations. Journal of Hospitality and Tourism. 22 (5), 767-783.

Tanford, S \& Jung, S. 2017. Festival Attributes and Perceptions: A meta-analysis of Relationships with Satisfaction and Loyality. Journal of Tourism Management. 61, 209-220.

Urban dan Stoltz. 2017. Multidimensional and Comparative Study on Intellectual Capital and Organisational Performance. Journal of Business Economics \& Management. 18 (1), p84-99. 


\section{Buku}

Chartered Institute of Management Accountants. 2012. Understanding Corporate Value: Managing and Reporting Intellectual Capital. United Kingdom: Cranfield University.

Freeman, R. E. 2010. Stakeholder Theory: The State Of The Art. New York: Cambridge University Press.

Sugiyono. 2012. Metode Penelitian Pendidikan (Pendekatan Kuantitatif, Kualitatif, dan $R \& D)$. Bandung: Alfabeta.

Sugiyono. 2015. Metode Penelitian Manajemen. Bandung: CV. Alfabeta.

\section{Skripsi, Tesis, Disertasi, dan Laporan Penelitian}

Ardiyasa, I. P. 2017. "Pembangunan Relasi Melalui Pemberdayaan Modal Intelektual: Pengelolaan Organisasi Papermoon Puppet Theatre". [Tesis]. Yogyakarta: Institut Seni Indonesia Yogyakarta.

\section{Narasumber}

Gregorius Djaduk Ferianto. Direktur Festival Ngayogjazz.

\section{Situs Web}

Aditya, I. 2017. Keberhasilan Organisasi Tergantung Pemimpinnya di http://krjogja.com Al-Hakimi, M. J. 2018. Ngayogjazz 2018 Negara Mawa Tata Jazz Mawa Cara di http://satuharapan.com

Dani, I. 2018. Ngayogjazz "Nang nDeso Ning Ora nDeso" di https://www.kompasiana.com

Kuo, T. Y, dkk. 2008. The Key Success Factors and Developing Strategies of Festivals in Taiwan di Huei-Mei Liang http://etd.lib.nsysu.edu.tw/ETD-db/ETD-search/view_etd?URN=etd-0818108151530

Maryono, D. 2017. Fungsi Seni Pertunjukan Bagi Masyarakat Terlengkap di https://ilmuseni.com

Riadi, M. 2017. Pengertian, Komponen, dan Pengukuran Intellectual Capital di https://www.kajianpustaka.com

Zukhronnee, M. 2018. Ngayogjazz 2018 Dijamin Spektakuler di htpp://koranbernas.id

(2008). Indikator Keberhasilan Sebuah Event di https://www.facebook.com/notes/universitas-gadjah-mada 